PHILIP CASS is editor of Pacific Journalism Review and a former Queensland journalist.

\section{New book explores never-ending Chamberlain \\ saga}

Feral Media: The Chamberlain Case 40 years On, by Belinda Middleweek. Melbourne: Australian Scholarly, 2021. 188 pages. ISBN 9781922454454.

HAVE only seen the Rock once and that was on a junket with TAA, flying a bunch of journos from a week in Perth back to Townsville via the Alice and Darwin. Our 727 circled in a banking turn over the big red monolith to give us all a good look. I never had the slightest desire to get any closer. Like anybody working and travelling in the North I knew what the bush was like-bloody hot and full of things that can kill you. The desert was even worse.

The only question I ever had about the Azaria Chamberlain case was why on earth the Chamberlains thought it sensible to take very young children on a camping trip to such a potentially hostile environment. As a parent, that always puzzled me.

Belinda Middleweek's new book, Feral Media, reviews the reporting

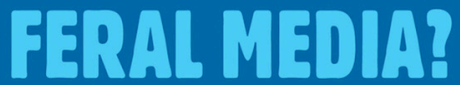

THE CHAMBERLAIN CASE, 40 YEARS ON

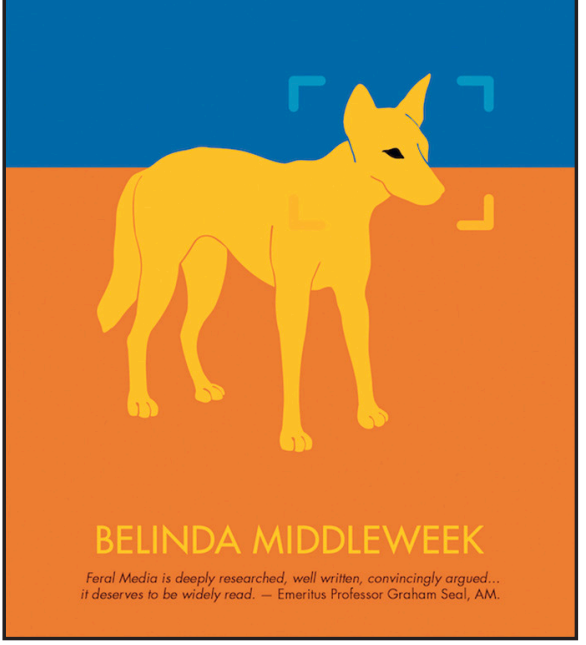

of the Azaria Chamberlain case, the way audience behaved and the way the decades-long saga became a media sensation that would not go away. The book examines in some detail the way in which the dingo who took the nine weeks-old Azaria became a central figure in the discourse of the trial, a media obsession that has remained stubbornly embedded in the national psyche.

I never really questioned the dingo theory. Even in Townsville, where I was running a farmers' newspaper, we were frequently contacted by people wanting to show us their slides of dingoes quietly opening eskies and wandering off with their booty. Experienced travellers and bushies would tell us time and again that dingoes were cunning, crafty and very quiet.

Reading Feral Media I wondered how much of the hostility to Lindy Chamberlain's claim that dingo took 
her baby was driven by an utter misunderstanding of how the bush worked by metropolitan journalists. Experience showed that metropolitan journalists' behaviour, expectations and understanding of how the outback worked were often a long way from those of regional and rural journalists.

None of the people, including local police, who were involved in the search for Azaria's body doubted she had been taken by a dingo. And yet somehow this evidence was discounted and what amounted to a witch hunt was launched, a witch hunt in which for decades the media has been deeply implicated.

The author properly points out the very different coverage of the saga by the Territory News reporter Frank Alcorta who took an activist role in the case. She argues that 'Frank Alcorta ... deserves to be singled out for issuing an ultimatum to the Northern Territory Government that forced Lindy's release from prison in 1986' (p. 132).

It is also worth remembering that the early stages of the Chamberlain saga were the period when the locally owned regional dailies were being sold off to southern and international conglomerates and local television news was being wiped out by the Hawke government's decision to open up the regional markets to metropolitan television. This meant that there was even less chance of any alternative views of Lindy Chamberlain and the disappearance of Azaria being heard outside the cities.

It is also worth questioning whether audiences outside the cities and es- pecially those living in the bush understood the story in quite the same way as their metropolitan cousins. Wherever they were, the role of the audience is central to Middleweek's book. Lindy Chamberlain seems to have taken a carefully nuanced view of the role of the audience in seemingly neverending saga, blaming them equally for feeding off the media hysteria:

Why blame the media? It is the public who demand the goods - so if there is no news today-well, spice it up to what the public wants or 'produce' some, and they do, and up go the reaction of demand and money and supply and greed.

None can be blamed alone. All must share-producer, reporter and consumer public (p. 6).

And yet, as Middleweek points out, some members of the audience were on her side, like the ones who contacted the media and offered us evidence of what dingoes were capable of and the ones who circulated pamphlets supporting Lindy Chamberlain and wrote to her in jail:

What is most interesting about the pamphleteers is the depth of their advocacy - they incited readers to act and speak out as a way of bolstering the pro-Chamberlain movement. The authors appealed to a 'widespread people' and 'thinking public' who were dissatisfied with the court's ruling. They understood how their writings could contribute to the formation of a majority consensus that would eventually see the Chamberlain convictions overturned. (p. 57) 